\title{
France's space efforts come down to Earth
}

Paris. France's Centre National d'Etudes Spatiales (CNES), the world's third largest space agency and the driving force behind Europe's space efforts, is changing gear. The shift reflects a change in the goals of its space programme from political to economic competitiveness following the end of the cold war, and a massive surge in French spending on military space programmes.

CNES was set up as a civilian space agency in 1961 to reinforce France's selfstyled status as an independent arbitrator between the two superpowers. Later, as the main contributor to the European Space Agency (ESA), France used its space efforts to back its claims to both technical and political leadership of Europe.

CNES's priorities have now changed. Maintaining independent access to space through ESA's French-led Ariane rocket programme remains a top priority. But, according to Jean-Daniel Levi, directorgeneral of CNES, the agency has been too preoccupied in recent years with supporting prestige projects such as the Hermès shuttle and the international space station.

This need not mean that ESA should abandon its plans to participate in the space station. If the United States and Russia continue a global project, Europe will be politically obliged to go along, he says. France could also "hypothetically" afford the project, he says, because it will have completed the most expensive phases of development of Ariane V by 1996.

But Levi warns that when ESA ministers sit down to decide how much support to give the space station next year, France's support will be conditional on the agency not making the mistake of letting the costs of the station "crush" its other activities.

This French pragmatism is relatively new. Gérard Longuet, the industry minister, wants CNES to move away from political goals towards improving the competitiveness of French industry. The 1994 budget for CNES reflects this shift. The total budget has increased by 3.4 per cent to FFr8.4 billion (US\$1.42 billion). But funding for space science rises 6.4 per cent to FFr1.7 billion; and for applications of space technology by 7.9 per cent to FFr1.1 billion.

Levi shares Longuet's thinking. This is one reason he wants to stop the recent escalation in CNES's contributions to ESA by freezing investment in new ESA programmes. France is the only European country to have maintained major national and bilateral space programmes alongside commitments to ESA, and wants to protect the budgets of these from further erosion.

Bilateral agreements are easier to manage than ESA programmes, especially in the operational phase, says Levi. Indeed, the success of the joint French-US altimetric satellite Topex-Poseidon, and the Frenchled SPOT Earth observation programmes, has been widely acclaimed. "This is how we see our future now," says Levi "But we will stay good Europeans."

In principle, CNES is well placed to increase its emphasis on developing the applications of space-based technology, such as Earth observation techniques and navigation systems. A showcase of the Colbertian

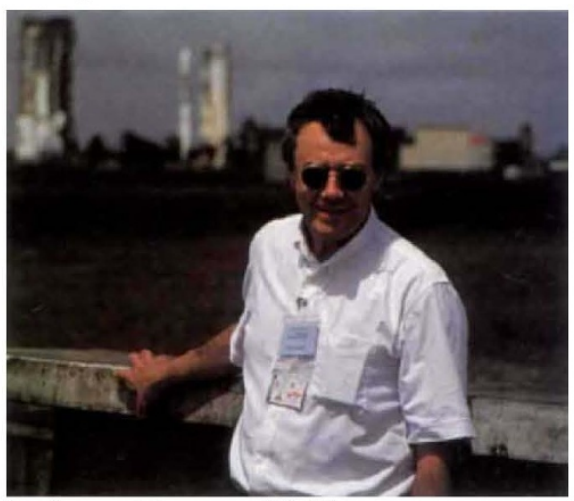

Levi: need for new thinking.

model of creating technology-based industries through massive public investment and planning, CNES - which has big stakes in four major companies - is the only national space agency in Europe able to take projects from conception to operation.

The potential economic impact of Earth observation, France's main national programme, is greater in the long-term than, for example, construction of infrastructure, the impact of which goes little further than the value of the construction contracts. A rise in the sale of images from SPOT, for example, creates a threefold increase in the market for the systems to handle them, and a tenfold increase in the market for the interpretation and use of the data.

But while the Arianespace company has been a success, it is not clear whether CNES can repeat this in creating new industries far downstream from its traditional areas of competence. Japan, for example, lags be-

hind Europe in satellite design, but has become the world leader in ground stations for telecommunications satellites.

Levi also says that the FFr485 million CNES will spend this year on 'advanced concepts' research such as artificial intelligence, robotics and new launch systems is not enough to keep pace with the "increasing ferocity" of international competition.

A plan to begin a programme of quick and small scientific missions may improve the situation by increasing the turnover of new technologies. In response to requests from researchers, CNES intends to start a programme of such experiments later this year. The time to launch will be reduced to just three years by using small Russian and Ukrainian launchers.

Another major policy change at CNES is a rapprochement with the French military. The Gulf war has convinced the army that battlefield superiority now depends on transferring ground-based systems command, control, communication, and intelligence systems into space.

The budget of the military space programme has rocketed from FFr697 million in 1987 to over FFr4 billion this year; and the French parliament's defence committee recently complained that even this growth is not enough to meet military needs.

CNES has always enjoyed close links with the military, sharing the same industrial base. These links were institutionalized last year when the Ministry of Defence was given shared responsibility for CNES. CNES is now developing a common strategy with the military space programme.

This use of the SPOT-4 platform for developing the Helios spy satellite, for example, has reduced costs by FFr1.3 billion. Even with such reductions, France cannot afford to pay for a complete military space system alone. But as Europe is still far from having a common defence policy, it will probably seek to share costs by pursing individual bilateral and multilateral programmes.

Declan Butler

\section{Wanted: good home for accelerator components}

Washington. The Department of Energy (DOE) and the state of Texas have asked for suggestions on what can be done with the various bits and pieces of the defunct Superconducting Super Collider (SSC).

The remnants of $\$ 2$ billion of public investment on the abandoned particle accelerator include "buildings for the linear accelerator as well as its negative hydrogen ion source and 2.5 million electron volt first stage (the higher energy sections are not complete); nearly 15 miles of tunnel; and an integrated network of distributed computer workstations", says a note from the DoE.
Other items for which a new use is being sought include a machine shop, half a million square feet of office space, and wellequipped magnet laboratories. Aspiring SSC carpetbaggers are invited to meet at Waxahachie on 22 March, with expressions of interest due in writing by 15 April.

As yet, this is not an asset sale. The DoE wants proposals for uses that will be good for science and - particularly pertinent to the impending legal battle between the federal government and Texas over the $\$ 400$ million which the state put into the project - good for Texas.

Colin Macilwain 